\title{
anu \\ QTL Identification for Stem Fiber, Strength and Rot Resistance in a DH Population from an Alien Introgression of Brassica napus
}

\author{
Yujiao Shao ${ }^{1}$, Yusen Shen ${ }^{2, *}\left(\mathbb{D}\right.$, Feifei $\mathrm{He}^{3}$ and Zaiyun $\mathrm{Li}^{4}$ \\ 1 College of Chemistry and Life Science, Hubei University of Education, Wuhan 430070, China; \\ syjsyj520@126.com \\ 2 Institute of Vegetables, Zhejiang Academy of Agricultural Sciences, Hangzhou 310021, China \\ 3 Department of Natural Sciences, Shantou Polytechnic, Shantou 515078, China; ffhe@stpt.edu.cn \\ 4 College of Plant Science and Technology, Huazhong Agricultural University, Wuhan 430070, China; \\ lizaiyun@mail.hzau.edu.cn \\ * Correspondence: yusen612@163.com
}

check for updates

Citation: Shao, Y.; Shen, Y.; He, F.; Li, Z. QTL Identification for Stem Fiber, Strength and Rot Resistance in a DH Population from an Alien Introgression of Brassica napus. Plants 2022, 11, 373. https://doi.org/ $10.3390 /$ plants 11030373

Academic Editor: Tae-Hwan Jun

Received: 25 December 2021

Accepted: 21 January 2022

Published: 29 January 2022

Publisher's Note: MDPI stays neutral with regard to jurisdictional claims in published maps and institutional affiliations.

Copyright: (C) 2022 by the authors. Licensee MDPI, Basel, Switzerland. This article is an open access article distributed under the terms and conditions of the Creative Commons Attribution (CC BY) license (https:// creativecommons.org/licenses/by/ $4.0 /)$.

\begin{abstract}
Stem fiber, stem strength and stem-rot resistance are important agronomic traits in Brassica napus. To understand the molecular mechanism that controls the stem-related traits, we investigated the stem lignin (ADL), cellulose (Cel), hemicellulose (Hem) content, S/G monolignol ratio (SG), stem breaking force (BF), breaking strength (F) and Sclerotinia sclerotiorum resistance (SSR). Each trait was significantly positively or negatively correlated with more than three of the other six traits. QTL mapping for ADL, Cel, Hem, SG, BF, F and SSR were performed using a doubled haploid population derived from an intertribal B. napus introgression line 'Y689' crossed with B. napus cv. 'Westar'. A total of 67 additive QTL were identified and integrated into 55 consensus QTL by meta-analysis. Among the 55 consensus QTL, 23 (41.8\%) QTL were co-located and were integrated into 11 unique QTL. The QTL by environment $(\mathrm{Q} \times \mathrm{E})$ interactions were analyzed and 22 combined QTL were identified. In addition, candidate genes within the QTL intervals were proposed based on the known function of Arabidopsis orthologs. These results provided valuable information for improving lodging resistance, $S$. sclerotiorum resistance and mechanized harvesting of $B$. napus.
\end{abstract}

Keywords: Brassica napus; lignin; stem strength; Sclerotinia sclerotiorum; QTL mapping

\section{Introduction}

Rapeseed (Brassica napus) is a widely grown crop that is used as vegetable oil for human, biodiesel energy for industry and feeding protein for animals. Fiber-related components, including lignin, cellulose (Cel) and hemicellulose (Hem), have played important roles in stem lodging [1,2], biomass digestibility [3] and Sclerotinia sclerotiorum (causing stem rot) resistance (SSR) $[4,5]$ in B. napus. Fibers are complex traits that are controlled by a number of genes [6]. Lignin is the most important fiber component and is composed of three units: syringyl (S), guaiacyl $(\mathrm{G})$ and p-hydroxyphenyl $(\mathrm{H})$ monolignols. As a dicot, $B$. napus primary contains $S$ and $G$ monolignols. Several lignin biosynthesis-related genes have been reported in Arabidopsis thaliana [7-10], rice [11,12], maize [13,14] and some ligneous plants [15-17].

In B. napus, seed fiber-related traits have been emphasized because of their effect on seed oil content and meal value. Some major QTL or candidate genes associated with seed acid detergent lignin (ADL) content have been identified [6,18-20]. For stem fiber-related traits, Wei et al. [2] uncovered eight and nine significant SNPs involved in ADL content and the syringyl/guaiacyl (S/G) monolignol ratio, respectively. Moreover, the S/G monolignol ratio was significantly negatively correlated with lodging resistance and stem disease susceptibility. A recent study proved that decreasing the $S / G$ ratio by knocking out of the 
lignin pathway gene, $B n F 5 H$, could improve the S. sclerotiorum resistance and increase stem strength [5].

Stem strength has been proposed as a key index of lodging resistance because of its difficulty for scoring lodging resistance under natural field conditions [21,22]. However, stem strength is a complex trait affected by related basal internode traits, such as stem diameter and cell wall components. The correlation between stem strength and cell wall components has not been elucidated in terms of the significance of cellulose or lignin [23]. Some progress of genetic studies on stem strength has been made in wheat [22,24,25], barley [26], rice [27], maize [28-30] and soybean [31,32]. In B. napus, stem strength has usually been studied along with lodging resistance. Wei et al. [2] decomposed stem strength into breaking force $(\mathrm{BF})$ and breaking strength $(\mathrm{F})$, and detected 11 and 7 significantly associated SNPs, respectively. One gene, BnaA01g26700D, encoding a TEOSINTE BRANCHED 1, CYCLOIDEA, PCF1 (TCP) transcription factor (TF), was deemed to be a candidate gene regulating stem strength. Li et al. [21] studied the stem lodging-related traits and identified 35 SNPs significantly associated with stem strength, which contributed to $23.3 \%$ of the cumulative phenotypic variation.

Sclerotinia sclerotiorum is a necrotrophic lifestyle fungal pathogen, which can cause $0-20 \%$ of yield loss every year in B. napus and can reach up to $80 \%$ in severely infected fields in China [33]. Very recently, some lignin biosynthesis pathway genes were reported to be related to S. sclerotiorum resistance in B. napus, such as BnF5H [5], BnCAD5 [34] and $B n a C . C C R 2$ [4]. These findings indicate that increasing the lignin content in the stems of B. napus might be an effective strategy for controlling S. sclerotiorum.

In the present study, we analyzed the phenotypic correlation of ADL, Cel, Hem, SG, $\mathrm{BF}, \mathrm{F}$ and SSR, and performed QTL mapping, meta-analysis and QTL by environment interaction analysis to dissect the genetic basis of these traits. Some fiber or disease related genes located within the QTL intervals were intended as candidate genes. These results may pave the way for deciphering the genetic control of stem-related traits in B. napus.

\section{Results}

\subsection{Phenotypic Performances of the Parents and DH Lines}

At maturity stage, the detached stems of the two parents ' $Y 689$ ' and 'Westar' as well as the control line 'Zhongyou 821' were inoculated with S. sclerotiorum. As a result, the level of resistance of ' $Y 689$ ' to S. sclerotiorum was significant compared to 'Westar' and 'Zhongyou 821' (Figure 1). We then examined histochemical transverse sections of the second stem internodes of the parents stained with phloroglucinol reagent, the vascular bundle regions were stained dark red in 'Y689' but were light red in 'Westar' (Figure 2a), indicating the higher lignin quantity of ' $Y 689$ ' than 'Westar'. The lignin compositions of the parents were also estimated by Mälue staining, with the Mäule reagent stains, $G$ residues yellow and S residues red. Fresh hand-cut internode sections of the two parents were stained red in the vascular bundle regions (Figure $2 b$ ), indicating that these regions contained abundant $S$ monomers. This result fit well with the measurement using the near-infrared spectroscopy (NIRS) method (Table 1).

Phenotypic data for ADL, Cel, Hem, SG, BF and $\mathrm{F}$ in the $\mathrm{DH}$ population were detected over four environments (14WH, 14ND, 15WH and 15ER), and SSR was detected over two environments (14WH and $15 \mathrm{WH})$. The BF, F and SSR of the two parents differed significantly in all experimental environments, whereas for the ADL, Cel, Hem and SG, significant differences $(p<0.05)$ were only detected in two or three environments. Statistical data of the seven traits for the DH population and the parents are listed in Table 1. The DH lines exhibited broad variations among the seven traits. Frequency distributions of the phenotypic values of the seven traits in the DH lines are shown in Figure 3. Among these traits, Cel and Hem differed significantly between the environments of $14 \mathrm{WH}$ and the others. SG differed significantly between $15 \mathrm{WH}$ and the other environments. F was significantly different between $14 \mathrm{ND}$ and the other environments. 

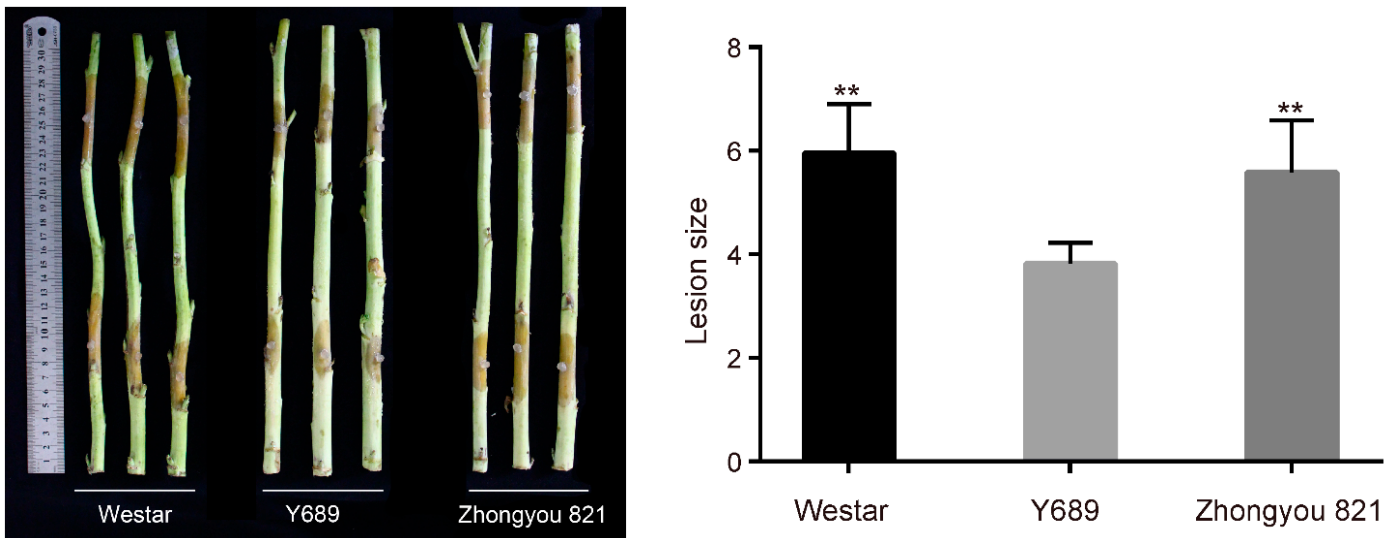

Figure 1. Resistance to Sclerotinia sclerotiorum of the two parents 'Westar' and 'Y689', and the control line 'Zhongyou 821 '. The level of resistance of 'Y689' to S. sclerotiorum was significant compared to 'Westar' and 'Zhongyou 821 '. ${ }^{* *}$ means the significance level between Y689 and the other two lines, $p \leq 0.01$.
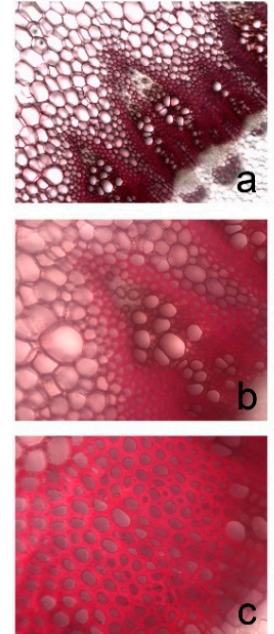

Y689
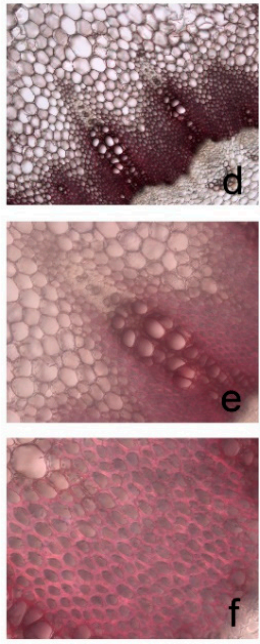

Westar

Phloroglucinol staining

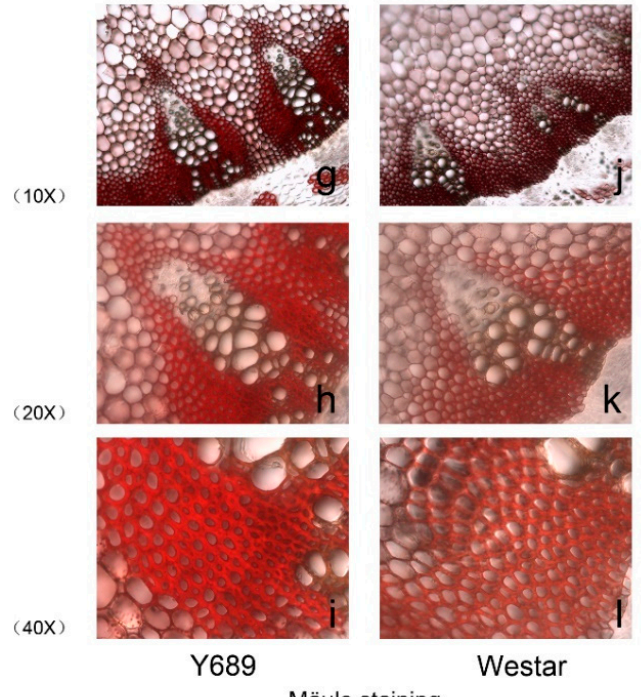

Mäule staining

Figure 2. Phloroglucinol and Mäule staining of 'Y689' and 'Westar'. (a-c) Transverse internode sections of 'Y689' after phloroglucinol staining. (d-f) Transverse internode sections of 'Westar' after phloroglucinol staining. The lignin quantity of 'Y689' is more than 'Westar'. (g-i) Transverse internode sections of 'Y689' after Mäule staining. (j-1) Transverse internode sections of 'Westar' after Mäule staining. The Mäule reagent stains: $G$ residues yellow and $S$ residues red. Magnification $10 \times$, $20 \times$, and $30 \times$.

Table 1. Statistical analysis of ADL, Cel, Hem, SG, BF, F and SSR for the DH lines and their parents.

\begin{tabular}{|c|c|c|c|c|c|c|c|c|}
\hline Trait & Environment & Parent Y689 & Parent Westar ${ }^{\text {a }}$ & $\begin{array}{c}\text { DH } \\
\text { Lines Range }\end{array}$ & Mean $\pm S D$ & Skewness & Kurtosis & Heritability \\
\hline \multirow[t]{4}{*}{$\mathrm{ADL}$} & $14 W H$ & $11.68 \pm 1.21$ & $10.91 \pm 1.53$ * & $8.31-13.83$ & $10.98 \pm 1.07$ & -0.18 & -0.25 & 0.66 \\
\hline & $14 \mathrm{ND}$ & $12.61 \pm 1.23$ & $11.67 \pm 2.53$ & $6.66-14.43$ & $11.28 \pm 1.42$ & -0.29 & 0.17 & \\
\hline & $15 \mathrm{WH}$ & $13.23 \pm 1.46$ & $12.55 \pm 1.52^{* *}$ & $10.25-14.88$ & $12.62 \pm 0.90$ & 0.09 & -0.21 & \\
\hline & 15ER & $12.69 \pm 1.32$ & $11.71 \pm 1.35^{* * *}$ & $9.10-15.34$ & $11.75 \pm 1.08$ & 0.28 & 0.23 & \\
\hline \multirow[t]{4}{*}{ Cel } & $14 \mathrm{WH}$ & $38.49 \pm 1.85$ & $36.88 \pm 1.23^{* *}$ & $33.37-42.63$ & $37.88 \pm 1.71$ & -0.16 & -0.18 & 0.79 \\
\hline & $14 N D$ & $46.51 \pm 1.64$ & $41.87 \pm 1.45$ & $38.98-48.61$ & $43.95 \pm 1.65$ & -0.28 & 0.39 & \\
\hline & $15 W H$ & $46.09 \pm 1.92$ & $44.02 \pm 1.63 *$ & $39.86-49.68$ & $45.20 \pm 1.77$ & -0.10 & 0.29 & \\
\hline & 15ER & $45.38 \pm 2.03$ & $42.81 \pm 2.05$ & $37.55-50.26$ & $43.68 \pm 2.34$ & -0.14 & 0.27 & \\
\hline \multirow[t]{4}{*}{ Hem } & $14 \mathrm{WH}$ & $18.58 \pm 1.23$ & $17.07 \pm 1.36^{* *}$ & $16.42-23.04$ & $20.00 \pm 1.29$ & -0.21 & -0.17 & 0.81 \\
\hline & $14 \mathrm{ND}$ & $20.38 \pm 1.32$ & $19.93 \pm 1.23 *$ & $14.10-20.06$ & $17.85 \pm 1.11$ & -0.50 & 0.34 & \\
\hline & $15 W H$ & $19.32 \pm 1.54$ & $14.71 \pm 1.87^{* * *}$ & $13.42-20.69$ & $17.31 \pm 1.33$ & -0.14 & 0.40 & \\
\hline & 15ER & $16.57 \pm 1.36$ & $15.43 \pm 1.65$ & $13.42-19.95$ & $16.62 \pm 1.30$ & -0.06 & -0.42 & \\
\hline
\end{tabular}


Table 1. Cont.

\begin{tabular}{|c|c|c|c|c|c|c|c|c|}
\hline Trait & Environment & Parent Y689 & Parent Westar ${ }^{a}$ & $\begin{array}{c}\text { DH } \\
\text { Lines Range }\end{array}$ & Mean \pm SD & Skewness & Kurtosis & Heritability \\
\hline \multirow[t]{4}{*}{ SG } & $14 \mathrm{WH}$ & $1.28 \pm 0.12$ & $1.18 \pm 0.26$ * & $0.84-1.75$ & $1.23 \pm 0.18$ & 0.24 & -0.16 & 0.56 \\
\hline & $14 \mathrm{ND}$ & $1.39 \pm 0.11$ & $1.21 \pm 0.15$ & $0.85-1.63$ & $1.24 \pm 0.14$ & -0.17 & -0.13 & \\
\hline & $15 \mathrm{WH}$ & $1.15 \pm 0.13$ & $1.05 \pm 0.16^{*}$ & $0.73-1.32$ & $1.01 \pm 0.10$ & 0.25 & 0.08 & \\
\hline & 15ER & $1.34 \pm 0.14$ & $1.11 \pm 0.24$ & $0.69-1.69$ & $1.20 \pm 0.16$ & 0.06 & 0.66 & \\
\hline \multirow[t]{4}{*}{$\mathrm{BF}$} & $14 \mathrm{WH}$ & $110.31 \pm 21.50$ & $59.68 \pm 25.30^{* * *}$ & $10.87-166.95$ & $73.04 \pm 30.11$ & 0.63 & 0.23 & 0.68 \\
\hline & $14 \mathrm{ND}$ & $141.43 \pm 22.30$ & $65.65 \pm 32.01^{* * *}$ & 23.15-180.30 & $84.11 \pm 33.22$ & 0.58 & 0.12 & \\
\hline & $15 \mathrm{WH}$ & $156.48 \pm 29.65$ & $82.79 \pm 24.56^{* * *}$ & $14.14-227.43$ & $74.21 \pm 34.97$ & 1.40 & 3.24 & \\
\hline & 15ER & $144.56 \pm 31.24$ & $87.95 \pm 23.15^{* * *}$ & $10.12-174.03$ & $69.07 \pm 30.71$ & 0.96 & 0.72 & \\
\hline \multirow[t]{4}{*}{$\mathrm{F}$} & $14 W H$ & $1.33 \pm 0.24$ & $0.66 \pm 0.32^{* * *}$ & $0.43-1.70$ & $0.97 \pm 0.25$ & 0.45 & 0.15 & 0.56 \\
\hline & $14 \mathrm{ND}$ & $0.84 \pm 0.13$ & $0.59 \pm 0.06^{* * *}$ & $0.31-1.10$ & $0.60 \pm 0.13$ & 0.30 & 0.33 & \\
\hline & $15 \mathrm{WH}$ & $1.97 \pm 0.56$ & $1.06 \pm 0.21^{* * *}$ & $0.44-2.36$ & $1.06 \pm 0.31$ & 1.20 & 3.22 & \\
\hline & 15ER & $1.38 \pm 0.47$ & $1.15 \pm 0.54^{* * *}$ & $0.46-1.56$ & $0.87 \pm 0.23$ & 0.79 & 0.34 & \\
\hline \multirow[t]{2}{*}{ SSR } & $14 \mathrm{WH}$ & $2.54 \pm 1.23$ & $5.86 \pm 1.36^{* * *}$ & $1.18-6.80$ & $4.03 \pm 1.14$ & 0.19 & -0.55 & 0.62 \\
\hline & $15 \mathrm{WH}$ & $1.87 \pm 2.35$ & $8.56 \pm 1.54^{* * *}$ & $1.00-9.94$ & $4.02 \pm 2.25$ & 0.64 & -0.45 & \\
\hline
\end{tabular}

a The significance level between two parents: ${ }^{*} p \leq 0.05 ;{ }^{* *} p \leq 0.01 ;{ }^{* * *} p \leq 0.001$.

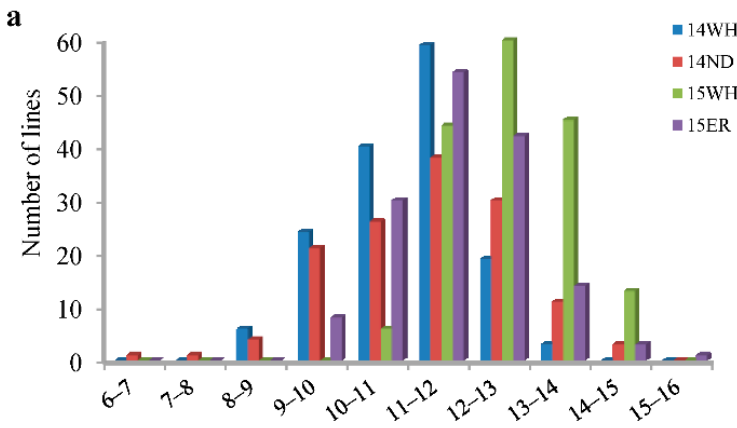

ADL

c

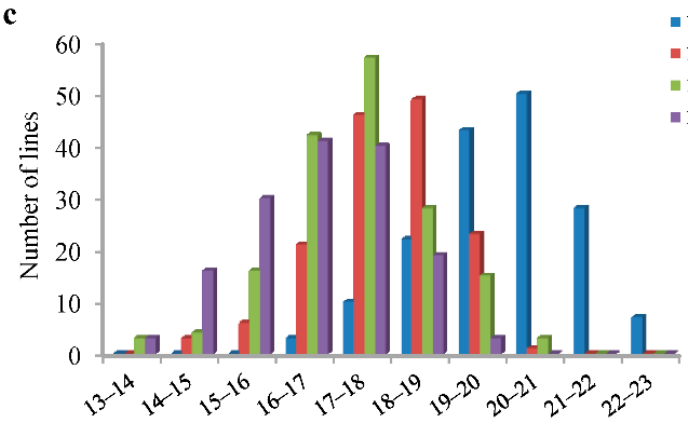

Hem

$\mathbf{e}$

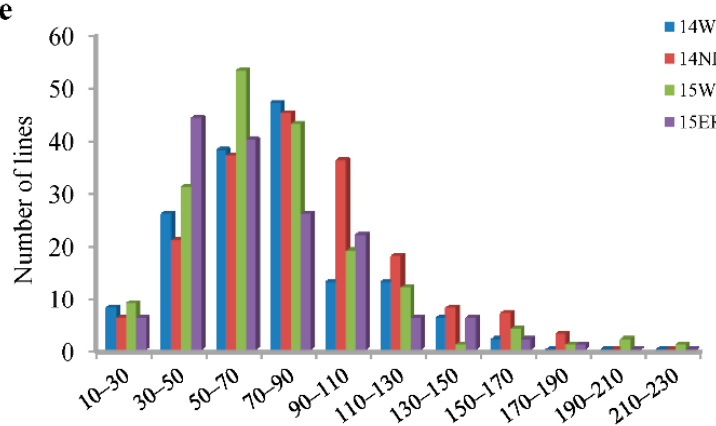

$\mathrm{BF}$

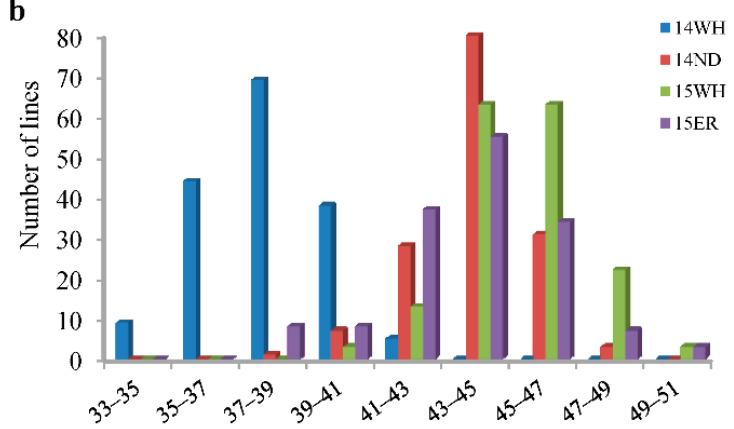

Cel

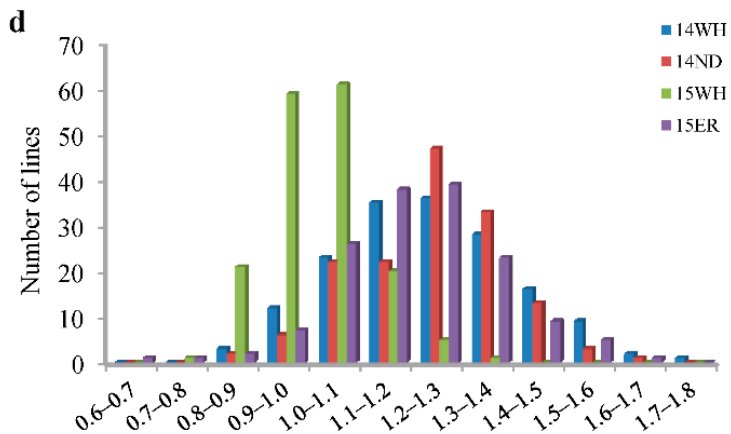

SG

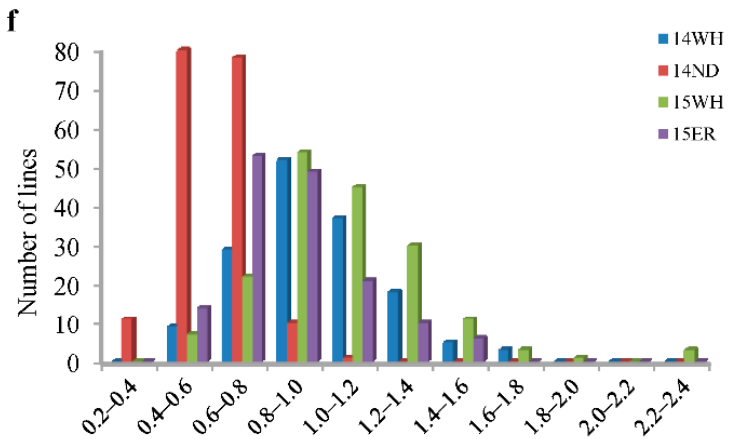

Figure 3. Cont 


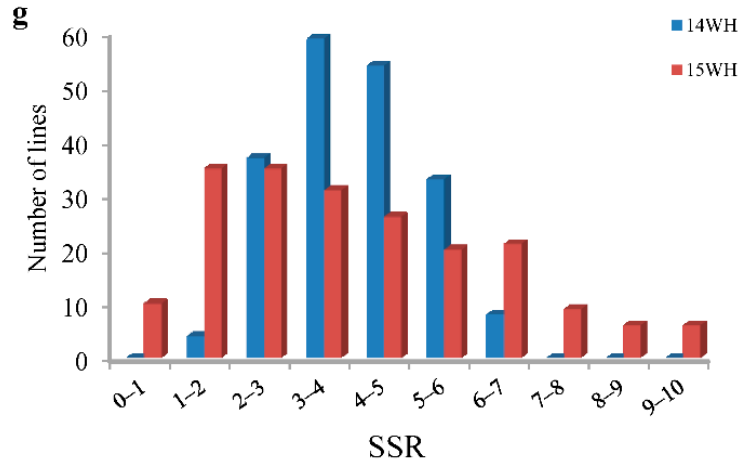

Figure 3. Phenotypic distributions of ADL, Cel, Hem, SG, BF, F and SSR in the YW-DH population derived from the cross 'Y $689^{\prime} \times$ 'Westar'. (a) Acid detergent lignin content, (b) cellulose content, (c) hemicellulose content, (d) syringyl/guaiacyl monolignol ratio, (e) breaking force, (f) breaking strength and (g) resistance against Sclerotinia sclerotiorum. 14WH, 14ND, 15WH and 15ER represent four environments with different colors. 14WH: Wuhan, 2014-2015; 14ND: Weinan, 2014-2015; 15WH, Wuhan, 2015-2016; 15ER, Ezhou, 2015-2016.

The broad-sense heritabilities $\left(h^{2}\right)$ of ADL, Cel, Hem, SG, BF, F and SSR were calculated as $0.66,0.79,0.81,0.56,0.68,0.56$ and 0.62 , respectively (Table 1 and Supplementary Table S1). Within the seven traits, SG and F presented lower heritability, indicating that these two traits were easily influenced by environmental factors. The Pearson's correlation coefficients between the seven traits ranged from 0.00 to 0.79 (Supplementary Table S2). Each trait was significantly positively or negatively correlated with more than three of the other six traits. For example, Cel was determined to be significantly positively correlated with Hem $(r=0.43, p<0.001)$ and SSR $(r=0.32, p<0.001)$, and negatively correlated with ADL $(r=-0.16, p<0.05), \mathrm{SG}(r=-0.16, p<0.001), \mathrm{BF}(r=-0.33, p<0.001)$ and F $(r=-0.39$, $p<0.001)$. In these comparisons, $\mathrm{BF}$ was highly correlated with $\mathrm{F}(r=0.79, p<0.001)$, probably because $F$ was calculated with the following formula: $F=B F /\left(\pi \times(D / 2)^{2}\right)$, where $\mathrm{D}$ was the diameter of the stem. Moreover, SSR was significantly positively correlated with Cel $(r=0.32, p<0.001)$ and significantly negatively correlated with BF $(-0.32, p<0.001)$ and $\mathrm{F}(-0.38, p<0.001)$, indicating that stems with higher breaking strength/force and lower cellulose content were more resistant against the disease caused by Sclerotinia sclerotiorum.

\subsection{Additive QTL Mapping and Meta-Analysis}

With the method of CIM, a total of 67 significant additive QTL were detected across 2 years (Table 2 and Figure 4 ). These QTL were primarily distributed on chromosomes C09 (11 QTL), C06 (10 QTL), A07 (9 QTL) and C03 (7 QTL), singly explaining 1.92-27.18\% of the phenotypic variation. Further, meta-analysis was used to integrate QTL across different environments (first round) and different traits (second round). In the first round of meta-analysis, 55 consensus QTL were detected, seven of which were major QTL. Notably, these major QTL were mainly clustered on Chromosomes A07 (112.5-120.35 cM) and C09 (116.79-123.5 cM) (Table 2).

For ADL, 11 additive QTL were detected and account for 5.58-16.57\% of the phenotypic variation. These QTL were then integrated into nine consensus QTL, with one QTL (cqADL.C09-3) considered to be a major QTL. For Cel, nine additive QTL were detected and accounted for $4.85-12.09 \%$ of the phenotypic variation. These QTL were integrated into eight consensus QTL, and no major QTL were detected. For Hem, five additive QTL were detected and accounted for 6.13-12.96\% of the phenotypic variation. These QTL were integrated into three consensus QTL, with one QTL (cqHem.A07-1) considered to be a major QTL. For SG, eight additive QTL were detected and accounted for 4.40-27.18\% of the phenotypic variation. These QTL were integrated into eight consensus QTL, with one QTL (cqSG.A07-1) found to be a major QTL. For BF and F, 7 and 16 additive QTL were identified, and accounted for $6.25-16.65 \%$ and $1.92-12.93 \%$ of the phenotypic variation, 
respectively. The QTL of cqBF.A07-2 was a major QTL for BF, which could be repeatedly detected in the environments of $14 \mathrm{WH}, 15 \mathrm{ER}$ and BLUE, with a mean PVE of $10.43 \%$. The QTL of cqF.C06-2 was a major QTL for F, which could be repeatedly detected in $14 \mathrm{WH}$ and 15ER, with a mean PVE of $14.89 \%$. For SSR, 11 additive QTL were detected and accounted for $4.91-17.11 \%$ of the phenotypic variation. These QTL were integrated into 10 consensus QTL, with two QTL (cqSSR.C09-1 and cqSSR.C09-2) considered to be major QTL. The QTL of cqSSR.C09-1 could be repeatedly detected in 15WH and BLUE, accounting for $12.64 \%$ and $14.26 \%$ of the phenotypic variation. The QTL of cqSSR.C09-2 could be detected in $14 \mathrm{WH}$, with the PVE of $17.11 \%$.

In the second round of meta-analysis, 23 of the 55 consensus QTL with overlapping regions were integrated into 11 unique QTL (Table 3). Of these, four unique QTL (uqA061, uqC01-1, uqC03-1 and uqC06-1) were pleiotropic for both SG and F, one unique QTL (uqC09-2) was pleiotropic for ADL, Cel and SSR. A high percentage (41.8\%) of the consensus QTL detected in different traits could be integrated into unique QTL, which were in accordance with the result that these traits were significantly correlated with one another (Supplementary Table S2).

\subsection{QTL by Environment Interaction Mapping}

Based on the phenotypic and genotypic data, QEI mapping was performed to verify the significantly additive QTL and to detect some probable interaction between additive QTL and the environments. As a result, a total of 22 combined QTL associated with ADL, Cel, Hem, SG, BF, F and SSR were identified, using LOD thresholds of 4.98, 5.07, 4.97, 5.04, $5.00,4.91$ and 3.84, respectively (Table 4). Of these, 15 QTL (68.2\%) were also detected by CIM, including five major QTL (IqADL.C09-1, IqHem.A07-1, IqBF.A07-1, IqF.C06-1 and IqSSR.C09-1). With these combined QTL, IqF.C06-1 associated with F presented the strongest QEI effect, with PVE (A) and PVE (A by E) values of 9.61 and 14.15, respectively. Two combined QTL (C07-1 and IqCel.C07-2) associated with Cel were not corresponding major consensus QTL, but exhibited a very strong QEI effect, which could explain $24.29 \%$ and $18.45 \%$ of the phenotypic variations. Furthermore, values of PVE (A) and PVE (A by E) were compared to evaluate the additive and QEI effect of each combined QTL. Consequently, the PVE (A by E) values in all five combined QTL associated with Hem and BF were larger than PVE (A), probably because Hem and BF were less influenced by environmental factors.

\subsection{Candidate Genes Mining}

According to the reference genome of B. napus [35] and the functional annotation of A. thaliana, 208 genes were harbored in all consensus QTL intervals corresponding to 142 homologous $A$. thaliana genes. A total of 18, 9, 6, 23, 44, 83 and 25 candidate genes were identified for ADL, Cel, Hem, SG, BF, F and SSR, respectively. For ADL, Cel, Hem and $\mathrm{SG}$, candidate genes were associated with fiber biosynthesis or regulation of the metabolic process, such as 4CL1, AtMYB103, WRKY13, PRX17, COMT-like1, LAC11, GH9A1, FEI1 and $B X L 2$. For $B F$ and $\mathrm{F}$, candidate genes were mainly associated with plant-type cell wall, such as EARLI1, RP1, PGK1, GAPC2, ASP2, TUB5, MCTP4, ACTIN3 and LRX1. For SSR, candidate genes belonged to NBS-LRR-encoding genes (Supplementary Table S3). 

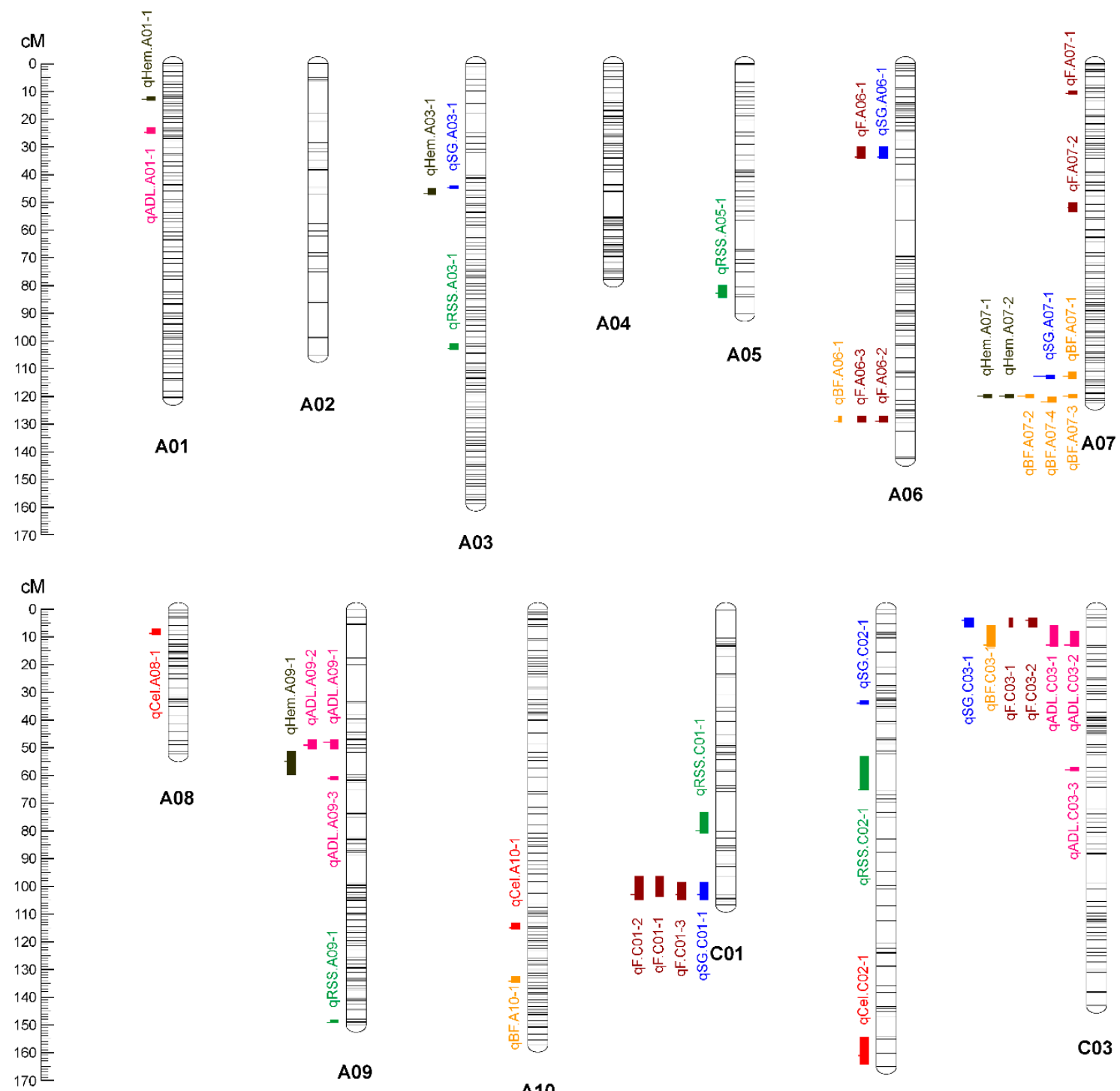

$\mathrm{A03}$
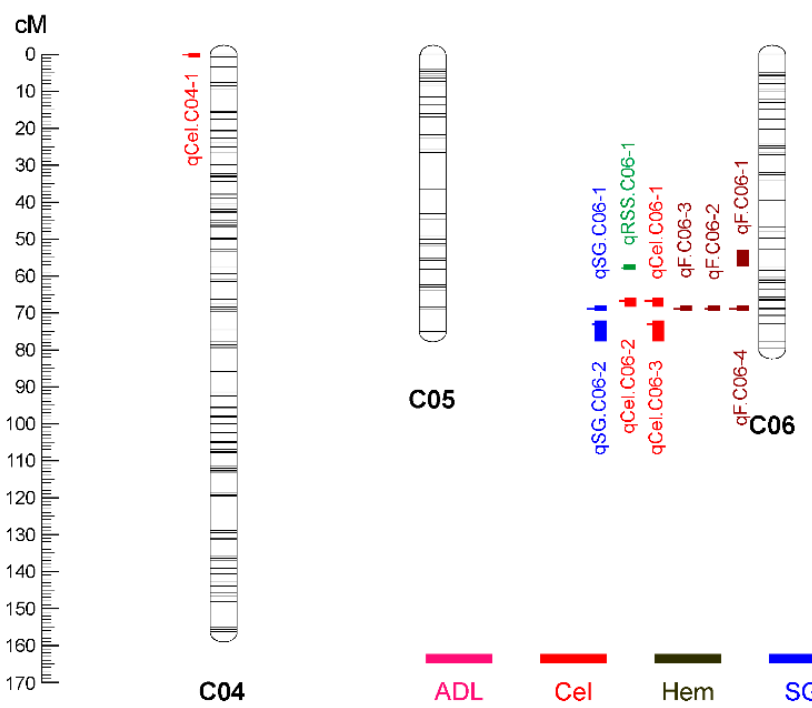

III
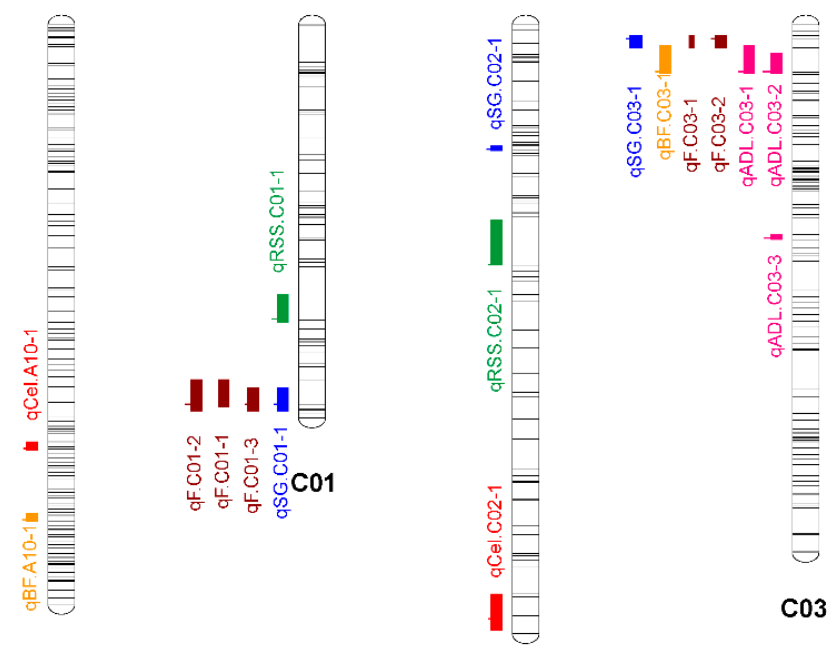

A10

$\mathrm{CO2}$

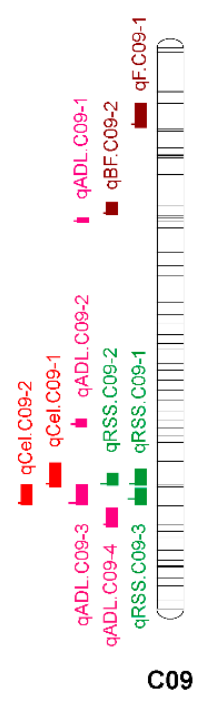

Figure 4. The identified QTL for ADL, Cel, Hem, SG, BF, F and SSR and their chromosome distribution. The length of the vertical bar in the " $\dashv$ " symbol indicates the confidence interval of the QTL, and the position of the horizontal bar indicates the peak position of the QTL. 
Table 2. Summary of the consensus QTL and their corresponding identified QTL used for QTL meta-analysis.

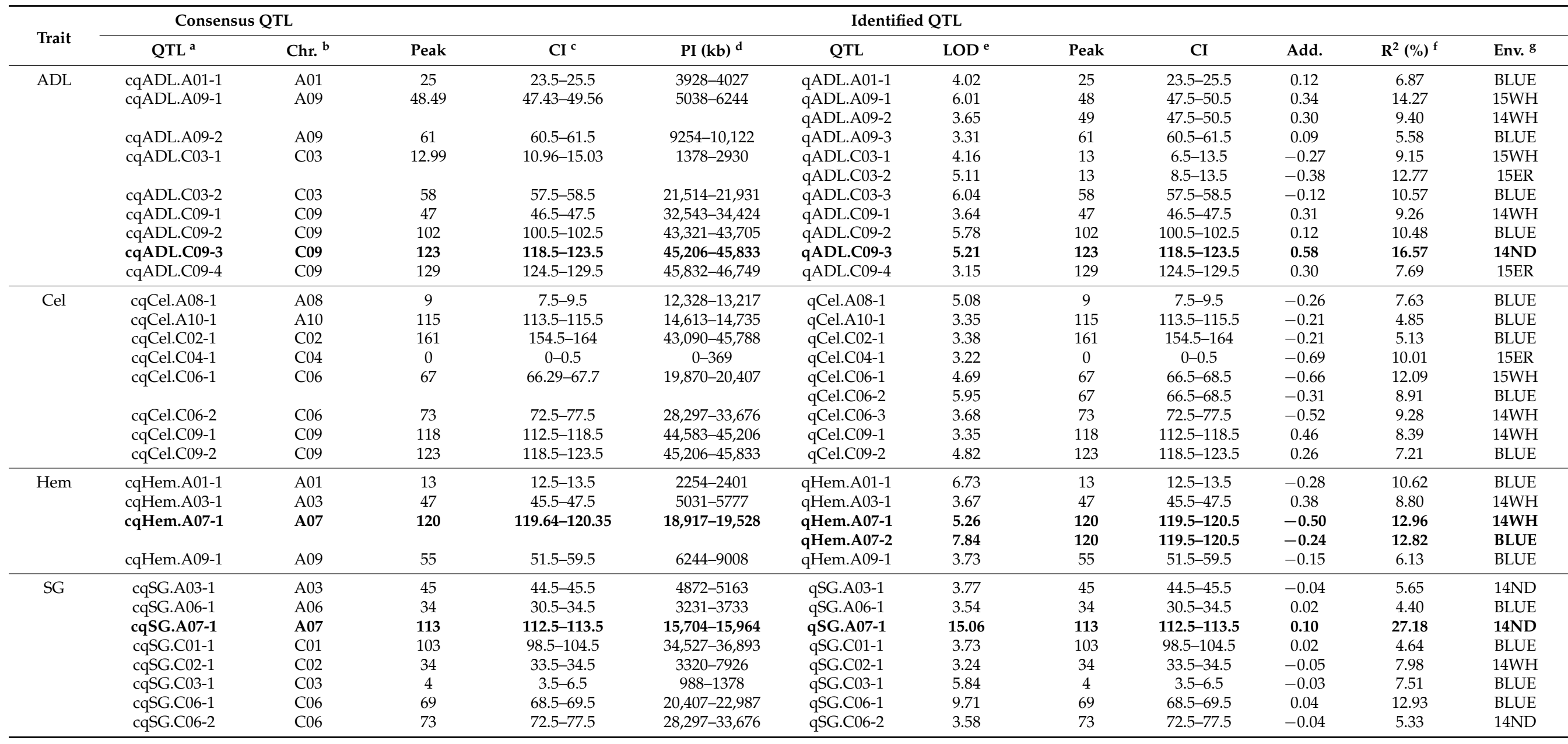


Table 2. Cont.

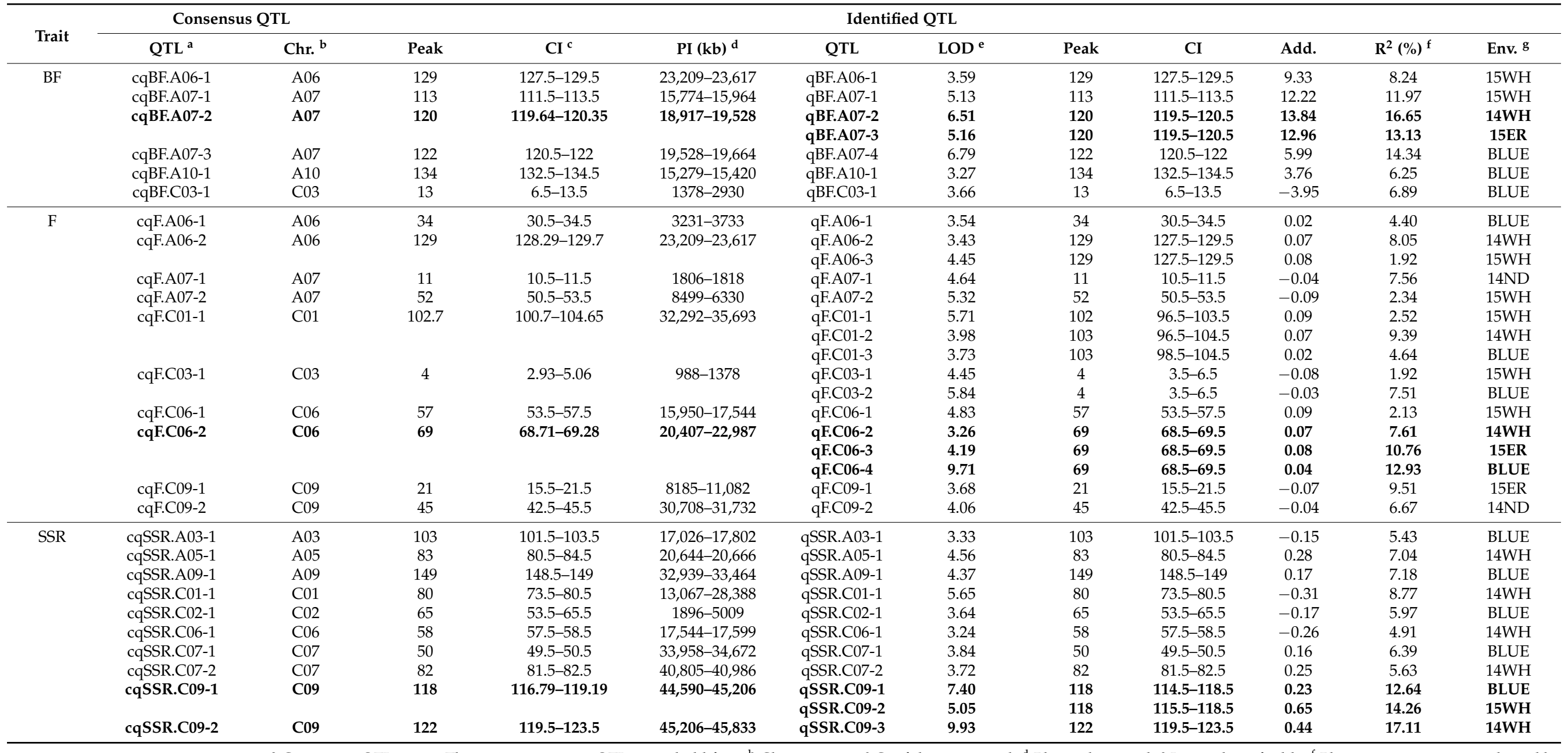

${ }^{a}$ Consensus QTL name. The major consensus QTL are in bold font. ${ }^{\mathrm{b}}$ Chromosome. ${ }^{\mathrm{c}}$ Confidence interval. ${ }^{\mathrm{d}}$ Physical interval. ${ }^{\mathrm{e}}$ Logarithm of odds. ${ }^{\mathrm{f}}$ Phenotypic variation explained by additive effect. $\mathrm{g}$ Environment. 
Table 3. Unique QTL information involved in more than two traits in this study.

\begin{tabular}{|c|c|c|c|c|c|c|c|}
\hline \multicolumn{2}{|c|}{ Unique QTL } & \multicolumn{6}{|c|}{ Consensus QTL } \\
\hline & Chr. ${ }^{a}$ & Peak & $\mathrm{CI}^{\mathrm{b}}$ & & Trait & Peak & CI \\
\hline \multirow[t]{2}{*}{ uqA06-1 } & A06 & 34 & $32.58-35.41$ & cqSG.A06-1 & SG & 34 & $30.5-34.5$ \\
\hline & & & & cqF.A06-1 & $\mathrm{F}$ & 34 & $30.5-34.5$ \\
\hline \multirow[t]{2}{*}{ uqA06-2 } & A06 & 129 & $128.42-129.57$ & cqBF.A06-1 & $\mathrm{BF}$ & 129 & $127.5-129.5$ \\
\hline & & & & cqF.A06-2 & $\mathrm{F}$ & 129 & 128.29-129.7 \\
\hline \multirow{2}{*}{ uqA07-1 } & A07 & 113 & $112.55-113.44$ & cqBF.A07-1 & $\mathrm{BF}$ & 113 & 111.5-113.5 \\
\hline & & & & cqSG.A07-1 & SG & 113 & $112.5-113.5$ \\
\hline uqA07-2 & $\mathrm{A} 07$ & 120 & $119.74-120.25$ & cqHem.A07-1 & Hem & 120 & $119.64-120.35$ \\
\hline \multirow[t]{2}{*}{ uqC01-1 } & $\mathrm{C} 01$ & 102.77 & $101.12-104.42$ & cqSG.C01-1 & SG & 103 & 98.5-104.5 \\
\hline & & & & cqF.C01-1 & $\mathrm{F}$ & 102.68 & $100.7-104.65$ \\
\hline \multirow[t]{2}{*}{ uqC03-1 } & $\mathrm{C} 03$ & 4 & $3.13-4.86$ & cqF.C03-1 & $\mathrm{F}$ & 4 & $2.93-5.06$ \\
\hline & & & & cqSG.C03-1 & SG & 4 & $3.5-6.5$ \\
\hline \multirow[t]{2}{*}{ uqC03-2 } & $\mathrm{C} 03$ & 12.99 & $11.23-14.75$ & cqBF.C03-1 & $\mathrm{BF}$ & 13 & $6.5-13.5$ \\
\hline & & & & cqADL.C03-1 & ADL & 12.99 & $10.96-15.03$ \\
\hline \multirow[t]{2}{*}{ uqC06-1 } & $\mathrm{C} 06$ & 69 & $68.75-69.24$ & cqSG.C06-1 & SG & 69 & $68.5-69.5$ \\
\hline & & & & cqF.C06-2 & $\mathrm{F}$ & 69 & $68.71-69.28$ \\
\hline uqC06-2 & $\mathrm{C} 06$ & 73 & $71.23-74.76$ & cqCel.C06-2 & Cel & 73 & $72.5-77.5$ \\
\hline \multirow[t]{2}{*}{ uqC09-1 } & C09 & 118 & 116.88-119.11 & cqCel.C09-1 & Cel & 118 & $112.5-118.5$ \\
\hline & & & & cqSSR.C09-1 & SSR & 118 & $116.79-119.19$ \\
\hline \multirow[t]{3}{*}{ uqC09-2 } & C09 & 122.56 & $121.23-123.88$ & cqADL.C09-3 & ADL & 123 & $118.5-123.5$ \\
\hline & & & & cqCel.C09-2 & Cel & 123 & 118.5-123.5 \\
\hline & & & & cqSSR.C09-2 & SSR & 122 & $119.5-123.5$ \\
\hline
\end{tabular}

${ }^{\mathrm{a}}$ Chromosome. ${ }^{\mathrm{b}}$ Confidence interval. 
Table 4. Summary of the combined QTL detected by QEI mapping.

\begin{tabular}{|c|c|c|c|c|c|c|c|c|c|c|c|c|}
\hline Trait & 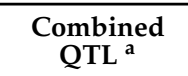 & Chr. ${ }^{b}$ & Pos. ${ }^{\mathrm{c}}$ & $\mathrm{CI}^{\mathrm{d}}$ & LOD $^{\mathrm{e}}$ & $\begin{array}{l}\text { LOD } \\
\text { (A) }{ }^{f}\end{array}$ & $\begin{array}{c}\text { LOD } \\
\text { (AbyE) } g\end{array}$ & PVE $^{h}$ & $\begin{array}{l}\text { PVE } \\
\text { (A) }{ }^{i}\end{array}$ & $\begin{array}{c}\text { PVE } \\
(\text { AbyE) } j\end{array}$ & Add $^{k}$ & $\begin{array}{c}\text { Consensus } \\
\text { QTL }^{1}\end{array}$ \\
\hline ADL & $\begin{array}{l}\text { IqADL.A09-1 } \\
\text { IqADL.C03-1 } \\
\text { IqADL.C03-2 } \\
\text { IqADL.C09-1 }\end{array}$ & $\begin{array}{l}\text { A09 } \\
\text { C03 } \\
\text { C03 } \\
\text { C09 }\end{array}$ & $\begin{array}{l}51 \\
13 \\
58 \\
\mathbf{1 2 3}\end{array}$ & $\begin{array}{c}50.5-51.5 \\
9.5-13.5 \\
57.5-58.5 \\
\mathbf{1 1 8 . 5 - 1 2 3 . 5}\end{array}$ & $\begin{array}{l}8.19 \\
8.53 \\
5.11 \\
\mathbf{6 . 1 6}\end{array}$ & $\begin{array}{l}3.86 \\
5.08 \\
3.99 \\
2.35 \\
\text { (A) }\end{array}$ & $\begin{array}{c}4.32 \\
3.44 \\
1.12 \\
3.81 \\
\text { (AbyE) g }\end{array}$ & $\begin{array}{l}6.26 \\
7.05 \\
4.57 \\
8.56\end{array}$ & $\begin{array}{l}3.62 \\
4.85 \\
3.77 \\
2.25 \\
\text { (A) }\end{array}$ & $\begin{array}{c}2.64 \\
2.20 \\
0.80 \\
\mathbf{6 . 3 2} \\
\text { (AbyE) } \mathbf{j}\end{array}$ & $\begin{array}{c}0.13 \\
-0.15 \\
-0.13 \\
\mathbf{0 . 1 0}\end{array}$ & $\begin{array}{l}\text { cqADL.C03-1 } \\
\text { cqADL.C03-2 } \\
\text { cqADL.C09-3 }\end{array}$ \\
\hline Cel & $\begin{array}{l}\text { IqCel.C02-1 } \\
\text { IqCel.C06-1 } \\
\text { IqCel.C07-1 } \\
\text { IqCel.C07-2 } \\
\text { IqCel.C09-1 }\end{array}$ & $\begin{array}{l}\mathrm{C} 02 \\
\mathrm{C} 06 \\
\mathrm{C} 07 \\
\mathrm{C} 07 \\
\mathrm{C} 09\end{array}$ & $\begin{array}{c}162 \\
67 \\
81 \\
83 \\
118\end{array}$ & $\begin{array}{c}156.5-164 \\
66.5-68.5 \\
80.5-81.5 \\
82.5-83.5 \\
116.5-118.5\end{array}$ & $\begin{array}{c}6.65 \\
5.63 \\
57.23 \\
48.65 \\
8.53\end{array}$ & $\begin{array}{c}5.13 \\
3.18 \\
26.20 \\
8.31 \\
7.72\end{array}$ & $\begin{array}{c}1.52 \\
2.44 \\
31.03 \\
40.35 \\
0.81\end{array}$ & $\begin{array}{c}2.49 \\
1.87 \\
24.29 \\
18.45 \\
2.66\end{array}$ & $\begin{array}{l}1.51 \\
1.00 \\
8.49 \\
2.58 \\
2.37\end{array}$ & $\begin{array}{c}0.98 \\
0.87 \\
15.79 \\
15.87 \\
0.29\end{array}$ & $\begin{array}{c}-0.24 \\
-0.22 \\
0.58 \\
-0.32 \\
0.31\end{array}$ & $\begin{array}{l}\text { cqCel.C02-1 } \\
\text { cqCel.C06-1 }\end{array}$ \\
\hline Hem & $\begin{array}{l}\text { IqHem.A01-1 } \\
\text { IqHem.A03-1 } \\
\text { IqHem.A07-1 }\end{array}$ & $\begin{array}{l}\text { A01 } \\
\text { A03 } \\
\text { A07 }\end{array}$ & $\begin{array}{l}15 \\
47 \\
\mathbf{1 2 0}\end{array}$ & $\begin{array}{c}14.5-15.5 \\
45.5-47.5 \\
\mathbf{1 1 9 . 5 - 1 2 0 . 5}\end{array}$ & $\begin{array}{c}6.63 \\
5.77 \\
\mathbf{1 0 . 1 1}\end{array}$ & $\begin{array}{l}6.01 \\
4.41 \\
\mathbf{9 . 2 8}\end{array}$ & $\begin{array}{l}0.62 \\
1.36 \\
\mathbf{0 . 8 4}\end{array}$ & $\begin{array}{l}3.42 \\
3.15 \\
5.76\end{array}$ & $\begin{array}{l}3.36 \\
2.47 \\
5.26\end{array}$ & $\begin{array}{l}0.06 \\
0.68 \\
\mathbf{0 . 5 0}\end{array}$ & $\begin{array}{c}-0.26 \\
0.16 \\
-\mathbf{0 . 2 5}\end{array}$ & $\begin{array}{l}\text { cqHem.A03-1 } \\
\text { cqHem.A07-1 }\end{array}$ \\
\hline SG & IqSG.A07-1 & A07 & 116 & $115.5-117.5$ & 13.87 & 2.23 & 11.63 & 22.34 & 4.16 & 18.18 & 0.01 & \\
\hline $\mathrm{BF}$ & $\begin{array}{l}\text { IqBF.A07-1 } \\
\text { IqBF.C03-1 }\end{array}$ & $\begin{array}{l}\mathbf{A 0 7} \\
\mathrm{C} 03\end{array}$ & $\begin{array}{l}\mathbf{1 2 0} \\
13\end{array}$ & $\begin{array}{c}119.5-120.5 \\
6.5-13.5\end{array}$ & $\begin{array}{l}\mathbf{9 . 7 2} \\
5.22\end{array}$ & $\begin{array}{l}4.59 \\
4.86\end{array}$ & $\begin{array}{l}\mathbf{5 . 1 3} \\
0.37\end{array}$ & $\begin{array}{c}\mathbf{1 0 . 0 9} \\
7.04\end{array}$ & $\begin{array}{l}5.43 \\
6.08\end{array}$ & $\begin{array}{l}4.65 \\
0.96\end{array}$ & $\begin{array}{c}4.34 \\
-4.31\end{array}$ & $\begin{array}{l}\text { cqBF.A07-2 } \\
\text { cqBF.C03-1 }\end{array}$ \\
\hline $\mathrm{F}$ & $\begin{array}{l}\text { IqF.C06-1 } \\
\text { IqF.C06-2 } \\
\text { IqF.C09-1 }\end{array}$ & $\begin{array}{l}\text { C06 } \\
\text { C06 } \\
\text { C09 }\end{array}$ & $\begin{array}{l}69 \\
72 \\
21\end{array}$ & $\begin{array}{l}\mathbf{6 8 . 5}-\mathbf{6 9 . 5} \\
71.5-72.5 \\
16.5-21.5\end{array}$ & $\begin{array}{c}40.70 \\
26.87 \\
6.62\end{array}$ & $\begin{array}{l}\mathbf{1 8 . 1 5} \\
2.32 \\
4.94\end{array}$ & $\begin{array}{c}22.55 \\
24.55 \\
1.68\end{array}$ & $\begin{array}{c}\mathbf{2 3 . 7 5} \\
13.36 \\
2.80\end{array}$ & $\begin{array}{l}\mathbf{9 . 6 1} \\
1.18 \\
2.45\end{array}$ & $\begin{array}{c}\mathbf{1 4 . 1 5} \\
12.18 \\
0.35\end{array}$ & $\begin{array}{c}\mathbf{0 . 0 7} \\
-0.02 \\
-0.03\end{array}$ & $\begin{array}{l}\text { cqF.C06-2 } \\
\text { cqF.C09-1 }\end{array}$ \\
\hline SSR & $\begin{array}{c}\text { IqSSR.A05-1 } \\
\text { IqSSR.C01-1 } \\
\text { IqSSR.C06-1 } \\
\text { IqSSR.C09-1 }\end{array}$ & $\begin{array}{l}\text { A05 } \\
\text { C01 } \\
\text { C06 } \\
\text { C09 }\end{array}$ & $\begin{array}{c}83 \\
80 \\
63 \\
\mathbf{1 2 2}\end{array}$ & $\begin{array}{c}80.5-84.5 \\
74.5-80.5 \\
61.5-65.5 \\
\mathbf{1 1 9 . 5 - 1 2 3 . 5}\end{array}$ & $\begin{array}{c}4.96 \\
5.48 \\
4.02 \\
\mathbf{1 0 . 3 0}\end{array}$ & $\begin{array}{l}0.59 \\
2.13 \\
1.33 \\
2.08\end{array}$ & $\begin{array}{l}4.38 \\
3.35 \\
2.69 \\
8.22\end{array}$ & $\begin{array}{c}5.72 \\
7.40 \\
5.08 \\
\mathbf{1 1 . 9 4}\end{array}$ & $\begin{array}{l}2.04 \\
6.70 \\
4.31 \\
\mathbf{6 . 4 0}\end{array}$ & $\begin{array}{l}3.68 \\
0.70 \\
0.78 \\
\mathbf{5 . 5 4}\end{array}$ & $\begin{array}{c}0.12 \\
-0.21 \\
-0.19 \\
\mathbf{0 . 2 1}\end{array}$ & $\begin{array}{l}\text { cqSSR.A05-1 } \\
\text { cqSSR.C01-1 } \\
\text { cqSSR.C09-2 }\end{array}$ \\
\hline
\end{tabular}

${ }^{a}$ Combined QTL is the QTL detected by QEI mapping with ICIM algorithm. The corresponding major consensus QTL detected by CIM algorithm are in bold font. ${ }^{\mathrm{b}}$ Chromosome. ${ }^{c}$ Chromosomal position (cM) of the peak. ${ }^{\mathrm{d}}$ Confidence interval. ${ }^{\mathrm{e}}$ LOD sore for additive and QEI effect. ${ }^{\mathrm{f}}$ LOD score for additive effect. ${ }^{\mathrm{g}}$ LOD score for QEI effect. ${ }^{\mathrm{h}}$ Phenotypic variation explained by additive and QEI effect. ${ }^{i}$ Phenotypic variation explained by additive effect. ${ }^{j}$ Phenotypic variation explained by $Q E I$ effect. ${ }^{k}$ Estimated average additive effect of the QTL. ${ }^{1}$ The corresponding major consensus QTL detected by CIM algorithm. 


\section{Discussion}

The stem-related traits of lignin, cellulose and hemicellulose can enhance the mechanical strength of the plant body, which is conducive to lodging resistance, convenient for mechanized harvesting, and can form barriers to pathogen infection. Moreover, the stem related traits have direct or indirect effects on yield because the plants with rigid stem can reduce lodging and enhance $S$. sclerotiorum resistance. In some reports, lodging has been shown to result in a yield reduction of as much as $46 \%$ [36] and S. sclerotiorum could cause 0-80\% yield loss in B. napus [33]. Therefore, it is very important to focus on the stem traits in contemporary B. napus breeding.

However, the genetic mechanism and the inner relationship of these traits have yet to be clarified in B. napus. Previously, we created an alien ingression line by intertribal hybridization between B. napus cv. 'Zhongyou821' and Capsella bursa-pastoris (L.) Medic $(2 \mathrm{n}=4 \mathrm{x}=32)$, and named it as ' $\mathrm{Y} 689$ '. This ingression line showed wooden stems, tight branch angles, and high resistance to $S$. sclerotiorum. These characters should result from the introgression of the genetic element from C. bursa-pastoris, which likely resulted in the longer growth period of ' $\mathrm{Y} 689^{\prime}$ than the recipient cultivar [37]. To better clarify the genetic basis of these traits, we constructed a DH population derived from the cross of ' $Y 689$ ' with B. napus cv. 'Wester', which was susceptible to S. sclerotiorum. In the present study, we analyzed the relationship between the fiber-related traits (lignin, cellulose, hemicellulose and S/G), stem strength (breaking force and strength) and the resistance to S. sclerotiorum. We found that the breaking strength (F) was significantly positively correlated with ADL, and significantly negatively correlated with SG and stem disease susceptibility (Supplementary Table S2), indicating that increasing the ADL content, especially the G proportion, could enhance the stem strength and disease resistance. G monolignol played a vital role in stem strength, which supported the result that decreasing the $S / G$ ratio could improve the S. sclerotiorum resistance in B. napus and increase stem strength [2,5]. Therefore, we could increase the ADL content and alter ADL composition to improve stem strength, lodging and S. sclerotiorum resistance in future breeding programs.

Accurate characterization of the phenotype influenced the results of QTL mapping. For a long time, lack of accurate determination of lignocellulose has limited the progress of genetic analysis in B. napus. As a quick assay for lignocellulosic component and property analysis, NIRS has been broadly applied in rice [38], Miscanthus samples [39] and B. napus [18]. In this study, we applied NIRS to determine the content of lignin, cellulose, hemicellulose and the $S / G$ monolignol ratio. In addition, the breaking force and stem diameter were measured to determine the stem strength. However, the stem diameter sometimes varied from different positions upon the stem. Moreover, stem strength was also affected by the positions of knots. In this study, we investigated the phenotyping data across four environments for stem fiber and strength-related traits, and two environments for S. sclerotiorum resistance. The BLUP value was calculated across all environments, which could enhance the accuracy of mapping results as it could give the lowest variance of the estimate linear estimators, and the errors do not need to be normal.

In this study, we performed QTL mapping based on the high-density linkage map and phenotypic data of the seven traits. This linkage map was also used for B. napus branch angle and plant architecture analysis in our previous publications [37,40], and many stable QTL were identified, indicating the reliability of this linkage map. Thus far, genetic analysis of stem fiber related traits in $B$. napus is limited to one study using GWAS and transcriptomic analyses [2]. To our knowledge, the present study is the first QTL mapping study for stem fiber and strength-related traits was performed based on a bi-parent population in B. napus. We compared the physical position of the two results, and found that only one QTL cqBF.A07-3 (A07:19,528-19,664 kb) associated with BF herein was close to the reported significant SNPs (A07: 20,909-20,962 kb). Other QTL regulating stem fiber and strength identified in this study were novel (Supplementary Table S4). For SSR, Li et al. [41] reviewed the reported QTL and found two conserved QTL regions (A09: $22.5-26.5 \mathrm{Mb}$ and $\mathrm{C} 06: 29.5$ to $35.4 \mathrm{Mb}$ ). We compared this result and the recent 
studies [42-44] with our result, and found the QTL identified in our result were novel (Supplementary Table S4). The detection of these new loci was largely attributable to the introduction of new gene sources for germplasm innovation via distant hybridizations.

By two-round meta-analysis, all the identified QTL were integrated into consensus QTL and further unique QTL. Many consensus QTL were co-located, and could be integrated into unique QTL, indicating that these QTL had pleiotropic effects or multiple genes that were tightly linked. Fine mapping will be necessary to determine the pleiotropic effects of a single QTL or a tight linkage of two QTL in the same region. These results were supported by the correlation analysis that significant correlations existed between the traits of stem fiber, stem strength and disease resistance (Supplementary Table S2).

QEI mapping was conducted to confirm the consensus QTL and estimate QEI effect. In this study, a total of 22 combined QTL were identified by QEI mapping, and some of the QTL presented a strong QEI effect. Of these, 15 QTL could be detected both by singleenvironment analysis and QEI mapping, which might be better ones for fine mapping and molecular breeding. For most of the combined QTL, the value of PVE (A by E) was lower than PVE (A), indicating the low QEI effect for most of the QTL. For some combined QTL, such as IqCel.C07-2, IqSG.A07-1 and IqF.C06-2, the value of PVE (A by E) was higher than PVE (A), suggesting the strong QEI effect that was detected.

Candidate genes for each trait were screened based on GO annotations. Some noteworthy candidate genes were identified in overlapping regions of fiber-related (ADL, Cel, Hem and SG) QTL. For instance, BnaC09g44570 corresponding to AT1G30230, encoded a guanine nucleotide exchange factor that played an important role in translation elongation. It was reported that silencing this gene could cause a dwarf phenotype with $38 \%$ and $20 \%$ reduction in total lignin and crystalline cellulose, respectively. This loss-of-function mutant also had a lower S/G lignin monomer ratio relative to wild type plants [45]. In addition, cqHem.A07-1 and cqBF.A07-2 were major co-located QTL associated with Hem and BF, respectively. In this region, BnaA07g26180 corresponding to AT1G02640 was identified as candidate gene, encoding a protein similar to a beta-xylosidase. It was reported that overexpressing this gene could increase enzymatic saccharification efficiency in cultured Arabidopsis wood cells [46].

\section{Materials and Methods}

\subsection{Plant Material and Growth Conditions}

The plant material consisted of $208 \mathrm{DH}$ lines developed from $\mathrm{F}_{1}$ plants of the cross 'Y689' $\times$ 'Westar' by microspore culture $[37,40]$. 'Y689' was an alien introgression line derived from the intertribal cross between B. napus cv. 'Zhongyou 821' and Capsella bursapastoris (L.) Medic $(2 \mathrm{n}=4 \mathrm{x}=32)$ [47]. ' $\mathrm{Y} 689$ ' showed rigid stems and high resistance to Sclerotinia sclerotiorum. Westar is a B. napus DH line widely used for the studies of genetic transformation [48] because of its high susceptibility to Sclerotinia sclerotiorum [49].

$\mathrm{DH}$ lines and the two parents were investigated in four experiments for ADL, Cel, Hem, SG, BF and F, and two experiments for SSR. The materials were planted in a semiwinter rapeseed area, Wuhan of Hubei Province (coded WH), in central China for two years (September-May of 2014-2015 and 2015-2016); Ezhou of Hubei Province (coded ER) for one year (September-May of 2015-2016); and a winter rapeseed area, Weinan of Shaanxi Province (coded ND), in northwest China rapeseed area for one year (September-May of 2014-2015). Year-location combinations were treated as environments, for example, $14 \mathrm{WH}$ indicates the experiment was conducted during 2014-2015 at the Wuhan location. Detailed information about the environments can be found in Supplementary Table S5.

The DH lines and the two parents were grown using a randomized complete block design with two replicates. Each plot consisted of 10 plants, with $30 \mathrm{~cm}$ between rows and $20 \mathrm{~cm}$ within rows. The field management followed the common agricultural practices. 


\subsection{Histochemical Staining}

According to the protocol established by [50], the histochemical localization of the accumulated lignin was stained with phloroglucinol reagent. Fresh hand-cut sections from the 'Y689' and 'Westar' plants were incubated for $10 \mathrm{~min}$ in phloroglucinol solution ( $1 \%$ in $70 \%$ ethanol), the phloroglucinol was removed and treated with $18 \% \mathrm{HCl}$ for $5 \mathrm{~min}$, then photographed under a light microscope.

Mäule staining was performed to detect the lignin composition. Sections were treated for 5 min with $\mathrm{KMnO}_{4}$, rinsed with water, treated with $10 \% \mathrm{HCl}$ for 5 min, rinsed again with water and mounted in concentrated $\mathrm{NH}_{4} \mathrm{OH}$ for examination [51].

\subsection{Phenotypic Evaluations and Statistical Analysis}

At maturity, six representative plants from the center of each plot were selected for measurements of ADL, Cel, Hem, SG, BF and F. A length of $30 \mathrm{~cm}$ fresh stems were detected to measure the breaking force $(\mathrm{BF})$ and the diameter $(D)$, using an electronic Vernier caliper. The breaking strength $(F)$ was calculated with the formula: $F=B F /\left(\pi \times(\mathrm{D} / 2)^{2}\right)$ [2].

Stem samples were then dried in a ventilated oven $\left(65^{\circ} \mathrm{C}\right)$ for about one week until the weight was constant. Based on the Near-infrared (NIR) models developed by Southwest University, Chongqing, China [2], the ADL, Cel, G and S monolignins were measured using NIR (FOSS, NIRS 5000) with the WinISI software.

At maturity, three representative plants from the center of each plot were detached to evaluate Sclerotinia sclerotiorum resistance. The S. sclerotiorum isolate was maintained and cultured on potato dextrose agar (PDA) medium in the dark at $22{ }^{\circ} \mathrm{C}$ and 6-mmdiameter mycelia agar plugs punched from the growing margin of a 3-day-old culture of S. sclerotiorum were used as inoculums [52]. Two 6-mm-diameter mycelia agar plugs were then placed above the $30 \mathrm{~cm}$ fresh stems with a 10-cm interval. Lesion sizes were measured after 3 days of inoculation with the infection temperature of $22{ }^{\circ} \mathrm{C}$ [53].

The data for each plant were averaged to represent the phenotype of a plot, and data from replicated plots were averaged to represent the phenotype of a DH line. Broad-sense heritability $\left(h^{2}\right)$ and correlations among all traits were analyzed using SAS GLM and CORR packages, respectively $[37,40]$.

\subsection{QTL Mapping}

The population and linkage map utilized in this study were also constructed for B. napus branch angle [40] and plant architecture [37] analyses in our previous publications. Briefly, the DH population was genotyped by B. napus $60 \mathrm{~K} \mathrm{SNP}$ array, and 3073 available SNP markers were screened for linkage map construction. This map covered a length of $2242.14 \mathrm{cM}$ and had an average marker interval of $0.73 \mathrm{cM}$ [40].

Based on the genotyping and phenotyping data, QTL analysis was conducted using QTL IciMapping V4.1 $[54,55]$ with the inclusive composite interval mapping (ICIM) method. The ICIM-BIP and ICIM-MET functionalities in this software were used for each experiment independently and for QTL-environment interaction analysis, respectively. The thresholds of the logarithm of the odds (LOD) scores for evaluating the statistical significance of QTL effects were determined using 1000 permutations at $95 \%$ confidence level.

QTL identified by the ICIM-BIP functionality were named as additive QTL. Through a two-round strategy of QTL meta-analysis [56], the additive QTL were integrated into consensus QTL for the same trait, and then the consensus QTL were integrated into unique QTL for different traits, using the software BioMercator V4.2 [57]. QTL identified by the ICIM-MET functionality were named as combined QTL.

The QTL nomenclature was based on the description of Shen et al. [40]. Additive QTL was designated with a " $\mathrm{q}$ " followed by the abbreviation of trait name, and the order on the chromosomes (e.g., qADL.A01-1). Consensus QTL, unique QTL and combined QTL were thus designated with the initial letters "cq-", "uq-", and "Iq-", (e.g., cqADL.A01-1, uqA06-1 and IqADL.A09-1), respectively. 


\subsection{Candidate Gene Mining}

The genetic linkage map could be aligned to the B. napus reference genome by BLAST. Based on the collinearity relationship between the genetic linkage map and the reference genome, genes within QTL regions were BLAST to the $A$. thaliana genome. These genes were further annotated with gene ontology (GO) terms, and genes belonging to related GO terms were regarded as potential candidate genes. For ADL and SG, the GO term was GO: 0009808 (lignin metabolic process). For Cel, the GO term was GO: 0030243 (cellulose metabolic process). For Hem, the GO term was GO: 0010410 (hemicellulose metabolic process). For BF and F, the GO term was GO: 0009505 (plant-type cell wall). For SSR, those encoding proteins containing NBS-LRR domains published from [35] were regarded as the most plausible candidate genes.

\section{Conclusions}

The stem lignin, cellulose, hemicellulose, syringyl/guaiacyl monolignol ratio, breaking force, breaking strength and S. sclerotiorum resistance were investigated in one $\mathrm{DH}$ population consisting of 208 lines in B. napus. We found that the breaking strength was significantly positively correlated with stem lignin content and S. sclerotiorum resistance, and significantly negatively correlated with the syringyl/guaiacyl monolignol ratio. QTL mapping was performed for these seven traits, and a total of 67 additive QTL were identified. These QTL were integrated into 55 consensus QTL, 23 of which were then integrated into 11 unique QTL by meta-analysis. To confirm the QTL reliability and assess the QTL by environment interaction (QEI) effect, QEI mapping was conducted and 22 combined QTL were identified. In addition, candidate genes within the QTL intervals were proposed based on the known function of Arabidopsis orthologs. One gene, BnaC09g44570, located in overlapping regions of fiber-related (ADL, Cel, Hem and SG) QTL, likely played an important role for fiber biosynthesis. These results provided valuable information for improving lodging resistance, S. sclerotiorum resistance and mechanized harvesting of B. napus.

Supplementary Materials: The following supporting information can be downloaded at: https: / / www.mdpi.com/article/10.3390/plants11030373/s1, Table S1: The broad-sense heritabilities of ADL, Cel, Hem, SG, BF, F, and SSR in this study, Table S2: Correlations between ADL, Cel, Hem, SG, BF, F, and SSR, based on the BLUE data, Table S3: List of the candidate genes in this study, Table S4: Comparative analysis of the QTL identified in the present and previous studies based on the B. napus genome sequences, Table S5: Summary of the environments where the parents and DH population were grown.

Author Contributions: Conceptualization, Y.S. (Yusen Shen); methodology, Y.S. (Yujiao Shao) and Y.S. (Yusen Shen); software, Y.S. (Yusen Shen); investigation, Y.S. (Yujiao Shao), F.H. and Y.S. (Yusen Shen); writing, Y.S. (Yusen Shen); project administration, Z.L. All authors have read and agreed to the published version of the manuscript.

Funding: This research received no external funding.

Institutional Review Board Statement: Not Applicable.

Informed Consent Statement: Not Applicable.

Data Availability Statement: Not applicable.

Conflicts of Interest: The authors declare no conflict of interest.

\section{References}

1. Wu, W.; Ma, B. A new method for assessing plant lodging and the impact of management options on lodging in canola crop production. Sci. Rep. 2016, 6, 31890. [CrossRef] [PubMed]

2. Wei, L.; Jian, H.; Lu, K.; Yin, N.; Wang, J.; Duan, X.; Li, W.; Liu, L.; Xu, X.; Wang, R.; et al. Genetic and transcriptomic analyses of lignin- and lodging-related traits in Brassica napus. Theor. Appl. Genet. 2017, 130, 1961-1973. [CrossRef] [PubMed]

3. Pei, Y.; Li, Y.; Zhang, Y.; Yu, C.; Fu, T.; Zou, J.; Tu, Y.; Peng, L.; Chen, P. G-lignin and hemicellulosic monosaccharides distinctively affect biomass digestibility in rapeseed. Bioresour. Technol. 2016, 203, 325-333. [CrossRef] [PubMed] 
4. $\quad$ Liu, D.; Wu, J.; Lin, L.; Li, P.; Li, S.; Wang, Y.; Li, J.; Sun, Q.; Liang, J.; Wang, Y. Overexpression of cinnamoyl-coA reductase 2 in Brassica napus increases resistance to Sclerotinia sclerotiorum by affecting lignin biosynthesis. Front. Plant Sci. 2021, 12, 732733. [CrossRef] [PubMed]

5. Cao, Y.; Yan, X.; Ran, S.; Ralph, J.; Smith, R.A.; Chen, X.; Qu, C.; Li, J.; Liu, L. Knockout of the lignin pathway gene BnF5H decreases the S/G lignin compositional ratio and improves S. sclerotiorum resistance in B. napus. Plant Cell Environ. 2021, 45, 248-261. [CrossRef]

6. Miao, L.; Chao, H.; Chen, L.; Wang, H.; Zhao, W.; Li, B.; Zhang, L.; Li, H.; Wang, B.; Li, M. Stable and novel QTL identification and new insights into the genetic networks affecting seed fiber traits in Brassica napus. Theor. Appl. Genet. 2019, 132, 1761-1775. [CrossRef]

7. Herrero, J.; Fernández-Pérez, F.; Yebra, T.; Novo-Uzal, E.; Pomar, F.; Pedreño, M.Á.; Cuello, J.; Guéra, A.; Esteban-Carrasco, A.; Zapata, J.M. Bioinformatic and functional characterization of the basic peroxidase 72 from Arabidopsis thaliana involved in lignin biosynthesis. Planta 2013, 237, 1599-1612. [CrossRef]

8. Zhang, K.; Bhuiya, M.-W.; Pazo, J.R.; Miao, Y.; Kim, H.; Ralph, J.; Liu, C.-J. An Engineered monolignol 4-O-methyltransferase depresses lignin biosynthesis and confers novel metabolic capability in Arabidopsis. Plant Cell 2012, 24, 3135-3152. [CrossRef]

9. Zhao, Q.; Nakashima, J.; Chen, F.; Yin, Y.; Fu, C.; Yun, J.; Shao, H.; Wang, X.; Wang, Z.-Y.; Dixon, R.A. LACCASE is necessary and nonredundant with PEROXIDASE for lignin polymerization during vascular development in Arabidopsis. Plant Cell 2013, 25, 3976-3987. [CrossRef]

10. Alejandro, S.; Lee, Y.; Tohge, T.; Sudre, D.; Osorio, S.; Park, J.; Bovet, L.; Lee, Y.; Geldner, N.; Fernie, A.R.; et al. AtABCG29 is a monolignol transporter involved in lignin biosynthesis. Curr. Biol. 2012, 22, 1207-1212. [CrossRef]

11. Liu, H.; Guo, Z.; Gu, F.; Ke, S.; Sun, D.; Dong, S.; Liu, W.; Huang, M.; Xiao, W.; Yang, G.; et al. 4-Coumarate-CoA ligase-like gene OsAAE3 negatively mediates the rice blast resistance, floret development and lignin biosynthesis. Front. Plant Sci. $2017,7,2041$. [CrossRef] [PubMed]

12. Wagner, A.; Tobimatsu, Y.; Phillips, L.; Flint, H.; Geddes, B.; Lu, F.; Ralph, J. Syringyl lignin production in conifers: Proof of concept in a Pine tracheary element system. Proc. Natl. Acad. Sci. USA 2015, 112, 6218-6223. [CrossRef] [PubMed]

13. Yang, Q.; He, Y.; Kabahuma, M.; Chaya, T.; Kelly, A.; Borrego, E.; Bian, Y.; El Kasmi, F.; Yang, L.; Teixeira, P.; et al. A gene encoding maize caffeoyl-CoA O-methyltransferase confers quantitative resistance to multiple pathogens. Nat. Genet. 2017, 49, 1364-1372. [CrossRef] [PubMed]

14. Eloy, N.B.; Voorend, W.; Lan, W.; Saleme, M.D.L.S.; Cesarino, I.; Vanholme, R.; Smith, R.A.; Goeminne, G.; Pallidis, A.; Morreel, K.; et al. Silencing CHALCONE SYNTHASE in Maize impedes the incorporation of tricin into lignin and increases lignin content. Plant Physiol. 2017, 173, 998-1016. [CrossRef] [PubMed]

15. Guo, H.; Wang, Y.; Wang, L.; Hu, P.; Wang, Y.; Jia, Y.; Zhang, C.; Zhang, Y.; Zhang, Y.; Wang, C.; et al. Expression of the MYB transcription factor gene BplMYB46 affects abiotic stress tolerance and secondary cell wall deposition in Betula platyphylla. Plant Biotechnol. J. 2017, 15, 107-121. [CrossRef]

16. Li, H.; Yang, Y.; Wang, Z.; Guo, X.; Liu, F.; Jiang, J.; Liu, G. BpMADS12 gene role in lignin biosynthesis of Betula platyphylla Suk by transcriptome analysis. J. For. Res. 2016, 27, 1111-1120. [CrossRef]

17. Acker, R.V.; Déjardin, A.; Desmet, S.; Hoengenaert, L.; Vanholme, R.; Morreel, K.; Laurans, F.; Kim, H.; Santoro, N.; Foster, C.; et al. Different routes for conifer- and sinapaldehyde and higher saccharification upon deficiency in the dehydrogenase CAD1. Plant Physiol. 2017, 175, 1018-1039. [CrossRef]

18. Liu, L.; Qu, C.; Wittkop, B.; Yi, B.; Xiao, Y.; He, Y.; Snowdon, R.J.; Li, J. A high-density SNP map for accurate mapping of seed fibre QTL in Brassica napus L. PLoS ONE 2013, 8, e83052. [CrossRef]

19. Behnke, N.; Suprianto, E.; Möllers, C. A major QTL on chromosome C05 significantly reduces acid detergent lignin (ADL) content and increases seed oil and protein content in oilseed rape (Brassica napus L.). Theor. Appl. Genet. 2018, 131, 2477-2492. [CrossRef]

20. Liu, L.; Stein, A.; Wittkop, B.; Sarvari, P.; Li, J.; Yan, X.; Dreyer, F.; Frauen, M.; Friedt, W.; Snowdon, R.J. A knockout mutation in the lignin biosynthesis gene CCR1 explains a major QTL for acid detergent lignin content in Brassica napus seeds. Theor. Appl. Genet. 2012, 124, 1573-1586. [CrossRef]

21. Li, H.; Cheng, X.; Zhang, L.; Hu, J.; Zhang, F.; Chen, B.; Xu, K.; Gao, G.; Li, H.; Li, L.; et al. An integration of genomewide association study and gene co-expression network analysis identifies candidate genes of stem lodging-related traits in brassica napus. Front. Plant Sci. 2018, 9, 796. [CrossRef] [PubMed]

22. Hai, L.; Guo, H.; Xiao, S.; Jiang, G.; Zhang, X.; Yan, C.; Xin, Z.; Jia, J. Quantitative trait loci (QTL) of stem strength and related traits in a doubled-haploid population of wheat (Triticum aestivum L.). Euphytica 2005, 141, 1-9. [CrossRef]

23. Wang, J.; Zhu, J.; Huang, R.; Yang, Y.S. Investigation of cell wall composition related to stem lodging resistance in wheat (Triticum aestivum L.) by FTIR spectroscopy. Plant Signal. Behav. 2012, 7, 856-863. [CrossRef]

24. Ma, Q.H. The expression of caffeic acid 3-O-methyltransferase in two wheat genotypes differing in lodging resistance. J. Exp. Bot. 2009, 60, 2763-2771. [CrossRef] [PubMed]

25. Miller, C.N.; Harper, A.L.; Trick, M.; Werner, P.; Waldron, K.; Bancroft, I. Elucidation of the genetic basis of variation for stem strength characteristics in bread wheat by Associative Transcriptomics. BMC Genom. 2016, 17, 500. [CrossRef] [PubMed]

26. Begović, L.; Abičić, I.; Lalić, A.; Lepeduš, H.; Cesar, V.; Leljak-Levanić, D. Lignin synthesis and accumulation in barley cultivars differing in their resistance to lodging. Plant Physiol. Biochem. 2018, 133, 142-148. [CrossRef] 
27. Long, W.; Dan, D.; Yuan, Z.; Chen, Y.; Jin, J.; Yang, W.; Zhang, Z.; Li, N.; Li, S. Deciphering the genetic basis of lodging resistance in wild rice oryza longistaminata. Front. Plant Sci. 2020, 11, 628. [CrossRef]

28. Liu, X.; Hu, X.; Li, K.; Liu, Z.; Wu, Y.; Wang, H.; Huang, C. Genetic mapping and genomic selection for maize stalk strength. BMC Plant Biol. 2020, 20, 196. [CrossRef]

29. Hu, H.; Liu, W.; Fu, Z.; Homann, L.; Technow, F.; Wang, H.; Song, C.; Li, S.; Melchinger, A.E.; Chen, S. QTL mapping of stalk bending strength in a recombinant inbred line maize population. Theor. Appl. Genet. 2013, 126, 2257-2266. [CrossRef]

30. Peiffer, J.A.; Flint-Garcia, S.A.; De Leon, N.; McMullen, M.D.; Kaeppler, S.M.; Buckler, E.S. The genetic architecture of maize stalk strength. PLoS ONE 2013, 8, e67066. [CrossRef]

31. Liu, W.; Zou, J.; Zhang, J.; Yang, F.; Wan, Y.; Yang, W. Evaluation of soybean (Glycine max) stem vining in maize-soybean relay strip intercropping system. Plant Prod. Sci. 2015, 18, 69-75. [CrossRef]

32. Chen, H.; Shan, Z.; Sha, A.; Wu, B.; Yang, Z.; Chen, S.; Zhou, R.; Zhou, X. Quantitative trait loci analysis of stem strength and related traits in soybean. Euphytica 2011, 179, 485-497. [CrossRef]

33. Wu, J.; Cai, G.; Tu, J.; Li, L.; Liu, S.; Luo, X.; Zhou, L.; Fan, C.; Zhou, Y. Identification of QTLs for resistance to Sclerotinia stem rot and BnaC.IGMT5.a as a candidate gene of the major resistant QTL SRC6 in Brassica napus. PLoS ONE 2013, 8, e67740. [CrossRef] [PubMed]

34. Höch, K.; Koopmann, B.; Tiedemann, A.V. Lignin composition and timing of cell wall lignification are involved in Brassica napus resistance to stem rot caused by Sclerotinia sclerotiorum. Phytopathology 2021, 111, 1438-1448. [CrossRef]

35. Chalhoub, B.; Denoeud, F.; Liu, S.; Parkin, I.A.P.; Tang, H.; Wang, X.; Chiquet, J.; Belcram, H.; Tong, C.; Samans, B.; et al. Early allopolyploid evolution in the post-Neolithic Brassica napus oilseed genome. Science 2014, 345, 950-953. [CrossRef]

36. Kendall, S.L.; Holmes, H.; White, C.A.; Clarke, S.M.; Berry, P.M. Quantifying lodging-induced yield losses in oilseed rape. Field Crop. Res. 2017, 211, 106-113. [CrossRef]

37. Shen, Y.; Xiang, Y.; Xu, E.; Ge, X.; Li, Z. Major co-localized QTL for plant height, branch initiation height, stem diameter, and flowering time in an alien introgression derived Brassica napus DH population. Front. Plant Sci. 2018, 9, 390. [CrossRef]

38. Jin, S.; Chen, H. Near-infrared analysis of the chemical composition of rice straw. Ind. Crop. Prod. 2007, 26, 207-211. [CrossRef]

39. Hayes, D.J.M. Development of near infrared spectroscopy models for the quantitative prediction of the lignocellulosic components of wet Miscanthus samples. Bioresour. Technol. 2012, 119, 393-405. [CrossRef]

40. Shen, Y.; Yang, Y.; Xu, E.; Ge, X.; Xiang, Y.; Li, Z. Novel and major QTL for branch angle detected by using DH population from an exotic introgression in rapeseed (Brassica napus L.). Theor. Appl. Genet. 2018, 131, 67-78. [CrossRef]

41. Li, J.; Zhao, Z.; Hayward, A.; Cheng, H.; Fu, D. Integration analysis of quantitative trait loci for resistance to Sclerotinia sclerotiorum in Brassica napus. Euphytica 2015, 205, 483-489. [CrossRef]

42. Wu, J.; Zhao, Q.; Liu, S.; Shahid, M.; Lan, L.; Cai, G.; Zhang, C.; Fan, C.; Wang, Y.; Zhou, Y. Genome-wide association study identifies new loci for resistance to sclerotinia stem rot in Brassica napus. Front. Plant Sci. 2016, 7, 1418. [CrossRef] [PubMed]

43. Wei, L.; Jian, H.; Lu, K.; Filardo, F.; Yin, N.; Liu, L.; Qu, C.; Li, W.; Du, H.; Li, J. Genome-wide association analysis and differential expression analysis of resistance to Sclerotinia stem rot in Brassica napus. Plant Biotechnol. J. 2016, 14, 1368-1380. [CrossRef] [PubMed]

44. Zhang, F.; Huang, J.; Tang, M.; Cheng, X.; Liu, Y.; Tong, C.; Yu, J.; Sadia, T.; Dong, C.; Liu, L.; et al. Syntenic quantitative trait loci and genomic divergence for Sclerotinia resistance and flowering time in Brassica napus. J. Integr. Plant Biol. 2019, 61, 75-88. [CrossRef] [PubMed]

45. Hossain, Z.; Amyot, L.; McGarvey, B.; Gruber, M.; Jung, J.; Hannoufa, A. The translation elongation factor eEF-1B $\beta 1$ is involved in cell wall biosynthesis and plant development in Arabidopsis thaliana. PLoS ONE 2012, 7, e30425. [CrossRef] [PubMed]

46. Ohtani, M.; Ramachandran, V.; Tokumoto, T.; Takebayashi, A.; Ihara, A.; Matsumoto, T.; Hiroyama, R.; Nishikubo, N.; Demura, T. Identification of novel factors that increase enzymatic saccharification efficiency in Arabidopsis wood cells. Plant Biotechnol. 2017, 34, 203-206. [CrossRef]

47. Chen, H.-F.; Wang, H.; Li, Z.-Y. Production and genetic analysis of partial hybrids in intertribal crosses between Brassica species (B. rapa, B. napus) and Capsella bursa-pastoris. Plant Cell Rep. 2007, 26, 1791-1800. [CrossRef]

48. Okuzaki, A.; Ogawa, T.; Koizuka, C.; Kaneko, K.; Inaba, M.; Imamura, J.; Koizuka, N. CRISPR/Cas9-mediated genome editing of the fatty acid desaturase 2 gene in Brassica napus. Plant Physiol. Biochem. 2018, 131, 63-69. [CrossRef]

49. Zhao, J.; Buchwaldt, L.; Rimmer, S.R.; Sharpe, A.; McGregor, L.; Bekkaoui, D.; Hegedus, D. Patterns of differential gene expression in Brassica napus cultivars infected with Sclerotinia sclerotiorum. Mol. Plant Pathol. 2009, 10, 635-649. [CrossRef]

50. Zhang, K.; Qian, Q.; Huang, Z.; Wang, Y.; Li, M.; Hong, L.; Zeng, D.; Gu, M.; Chu, C.; Cheng, Z. GOLD HULL AND INTERNODE2 encodes a primarily multifunctional cinnamyl-alcohol dehydrogenase in rice. Plant Physiol. 2006, 140, 972-983. [CrossRef]

51. Chapple, C.C.S.; Vogt, T.; Ellis, B.E.; Somerville, C.R. An arabidopsis mutant defective in the general phenylpropanoid pathway. Plant Cell 1992, 4, 1413-1424. [PubMed]

52. Mei, J.; Qian, L.; Disi, J.O.; Yang, X.; Li, Q.; Li, J.; Frauen, M.; Cai, D.; Qian, W. Identification of resistant sources against Sclerotinia sclerotiorum in Brassica species with emphasis on B. oleracea. Euphytica 2011, 177, 393-399. [CrossRef]

53. Mei, J.; Ding, Y.; Lu, K.; Wei, D.; Liu, Y.; Disi, J.O.; Li, J.; Liu, L.; Liu, S.; McKay, J.; et al. Identification of genomic regions involved in resistance against Sclerotinia sclerotiorum from wild Brassica oleracea. Theor. Appl. Genet. 2013, 126, 549-556. [CrossRef] [PubMed]

54. Meng, L.; Li, H.; Zhang, L.; Wang, J. QTL IciMapping: Integrated software for genetic linkage map construction and quantitative trait locus mapping in biparental populations. Crop J. 2015, 3, 269-283. [CrossRef] 
55. Wang, J. Inclusive composite interval mapping of quantitative trait genes. Acta Agron. Sin. 2009, 35, 239-245. [CrossRef]

56. Shi, J.; Li, R.; Qiu, D.; Jiang, C.; Long, Y.; Morgan, C.; Bancroft, I.; Zhao, J.; Meng, J. Unraveling the complex trait of crop yield with quantitative trait loci mapping in Brassica napus. Genetics 2009, 182, 851-861. [CrossRef]

57. Sosnowski, O.; Charcosset, A.; Joets, J. BioMercator V3: An upgrade of genetic map compilation and quantitative trait loci meta-analysis algorithms. Bioinformatics 2012, 28, 2082-2083. [CrossRef] 